\title{
Perspective
}

Published online: October 15, 2014

DOI: $10.1159 / 000368563$

\section{The Endothelin Pathway: A Protective or Detrimental Target of Bardoxolone Methyl on Cardiac Function in Patients with Advanced Chronic Kidney Disease?}

\author{
Danielle Camer Xu-Feng Huang \\ School of Medicine, and Illawarra Health and Medical Research Institute, University of Wollongong, \\ Wollongong, NSW, Australia
}

\section{Key Words}

Endothelin · Kidney · Renal · Heart · Bardoxolone methyl

\begin{abstract}
Bardoxolone methyl has been reported to cause detrimental cardiovascular events in the terminated BEACON Phase III human clinical trial via modulation of the renal endothelin pathway. However, the effects of bardoxolone methyl administration on the endothelin pathway in the heart are unknown. Our purpose in this perspective is to highlight the distinctive opposing roles of the renal and heart endothelin pathway in cardiac function. Furthermore, we address the need for further investigation in order to determine if bardoxolone methyl has a protective role in cardiac function through the suppression of the endothelin pathway in the heart.

(c) 2014 S. Karger AG, Basel
\end{abstract}

The paradoxical nature of bardoxolone methyl (BM) has been widely noted in recent scientific literature [1]. There are many known anti-inflammatory and anti-oxidative properties of this drug that have shown promise in preclinical studies, including treating complications of diabetes such as retinopathy and nephropathy [2]. In addition, phases 1 and II of human clinical trials in patients with chronic kidney disease found that BM markedly improved kidney function $[3,4]$. These positive results from the earlier phases led to the BEACON phase III human clinical trial in patients with type 2 diabetes and stage 4 chronic kidney disease [5]. However, this trial was terminated due to safety concerns centred on an increased incidence of cardiovascular events in BM-treated patients compared to the placebo group [6]. This has led to skepticism in the scientific community as to whether BM will ever be used in the future treatment of diseases such as chronic kidney disease.

\section{KARGER}

E-Mail karger@karger.com www.karger.com/ajn
C 2014 S. Karger AG, Basel

$0250-8095 / 14 / 0403-0288 \$ 39.50 / 0$
Professor Xu-Feng Huang, MD, PhD, DSc

Illawarra Health and Medical Research Institute School of Medicine, University of Wollongong

Northfields Avenue, NSW, 2522 (Australia)

E-Mail xhuang@uow.edu.au 
Table 1. Summary of endothelin system functions in the kidneys and vascular system

\begin{tabular}{llll}
\hline & ET-1 & ET $_{\mathrm{A}}$ receptors & ET $_{\mathrm{B}}$ receptors \\
\hline Kidneys & $\begin{array}{l}\text { Regulates sodium } \\
\text { and water homeostasis }\end{array}$ & $\begin{array}{l}\text { Vasoconstrictor } \\
\text { and sodium retention } \\
\text { effects }\end{array}$ & $\begin{array}{l}\text { Involved in water } \\
\text { and sodium } \\
\text { reabsorption and } \\
\text { inhibiting vasopressin } \\
\text { activity }\end{array}$ \\
$\begin{array}{l}\text { Vascular } \\
\text { system }\end{array}$ & $\begin{array}{l}\text { Regulates vascular tone, } \\
\text { cardiac hypertrophy and } \\
\text { blood pressure }\end{array}$ & $\begin{array}{l}\text { Vasoconstrictor } \\
\text { (smooth muscle) }\end{array}$ & $\begin{array}{l}\text { Vasoconstrictor } \\
\text { (smooth muscle) and } \\
\text { vasodilator } \\
\text { (endothelial cells) }\end{array}$ \\
\hline
\end{tabular}

Mechanisms contributing to adverse cardiovascular events seen in patients treated with BM in the BEACON trial have since been addressed [7]. It was concluded that the modulation of the endothelin pathway provided an explanation of the mechanisms by which BM caused an increase in cardiovascular events in participants. It was also found that BM was able to suppress the endothelin pathway in the kidneys of chronic kidney disease (CKD)-induced rodents and healthy cynomolgus monkeys by reducing the protein expression of the $\mathrm{ET}_{\mathrm{A}}$ receptor [7]. In healthy cynomolgus monkeys, $\mathrm{BM}$ did not affect the $\mathrm{ET}_{\mathrm{B}}$ receptor expression [7]. However, in rodents induced with $\mathrm{CKD}, \mathrm{BM}$ restored $\mathrm{ET}_{\mathrm{B}}$ receptor levels to those observed in the control animals [7]. Thus, these results are extremely important in trying to explain the detrimental cardiovascular events that occurred in a number of patients taking BM in this human clinical trial. Despite this, there are limitations in arriving at this conclusion because only the endothelin pathway of kidney tissue was examined and not the cardiac tissue.

It is well established that renal endothelin 1 (ET-1) has several important functions including regulating sodium and water homeostasis, renal blood flow and acid base balance via activation of $\mathrm{ET}_{\mathrm{A}}$ and $\mathrm{ET}_{\mathrm{B}}$ receptors [8] (Table 1). Furthermore, if the endothelin system is suppressed, such as from being targeted by BM, this balance is disturbed causing fluid retention, which can lead to heart failure [8]. However, it is important to note that the endothelin pathway in the heart has a different function with regard to the kidneys. ET-1 in the cardiac muscle promotes cardiac hypertrophy and subsequent heart failure via activation of $\mathrm{ET}_{\mathrm{A}}$ receptors [9] (table 1). Furthermore, both $\mathrm{ET}_{\mathrm{A}}$ receptor and com- bined $\mathrm{ET}_{\mathrm{A}} / \mathrm{ET}_{\mathrm{B}}$ receptor antagonism have been shown to lower blood pressure and reduce the infarct size in patients with congestive heart failure [9]. Thus, suppressing the endothelin pathway in the heart would be protective against adverse cardiovascular vascular events.

In our opinion, due to the differing functions of the endothelin pathway in the kidneys and heart, we feel that more evidence is required to conclude that BM treatment causes adverse cardiovascular events by suppressing the renal endothelin pathway. Future investigation of the effects of BM on cardiac tissue is required in order to determine if $\mathrm{BM}$ inhibits $\mathrm{ET}_{\mathrm{A}}$ receptors in the heart causing its protection.

References

Van Laecke S, Van Biesen W, Vanholder R: The paradox of bardoxolone methyl: a call for every witness on the stand? Diabetes Obes Metab 2014. DOI: 10.1111/dom.12356 [Epub ahead of print].

2 Camer D, Yu Y, Szabo A, Huang XF: The molecular mechanisms underpinning the therapeutic properties of oleanolic acid, its isomer and derivatives for type 2 diabetes and associated complications. Mol Nutr Food Res 2014; 58:1750-1759.

-3 Pergola PE, Raskin P, Toto RD, Meyer CJ, Huff JW, Grossman EB, Krauth M, Ruiz S, Audhya P, Christ-Schmidt H, Wittes J, Warnock DG: Bardoxolone methyl and kidney function in CKD with type 2 diabetes. $\mathrm{N}$ Engl J Med 2011;365:327-336.

4 Pergola PE, Krauth M, Huff JW, Ferguson DA, Ruiz S, Meyer CJ, Warnock DG: Effect of bardoxolone methyl on kidney function in patients with T2D and Stage 3b-4 CKD. Am J Nephrol 2011;33:469-476. 
5 de Zeeuw D, Akizawa T, Agarwal R, Audhya P, Bakris GL, Chin M, Krauth M, Lambers Heerspink HJ, Meyer CJ, McMurray JJ, Parving $\mathrm{HH}$, Pergola PE, Remuzzi G, Toto RD, Vaziri ND, Wanner C, Warnock DG, Wittes J, Chertow GM: Rationale and trial design of Bardoxolone Methyl Evaluation in Patients with Chronic Kidney Disease and Type 2 Diabetes: the Occurrence of Renal Events (BEACON). Am J Nephrol 2013;37:212-222.
6 de Zeeuw D, Akizawa T, Audhya P, Bakris GL, Chin M, Christ-Schmidt H, Goldsberry A, Houser M, Krauth M, Lambers Heerspink HJ, McMurray JJ, Meyer CJ, Parving HH, Remuzzi G, Toto RD, Vaziri ND, Wanner C, Wittes J, Wrolstad D, Chertow GM: Bardoxolone methyl in type 2 diabetes and stage 4 chronic kidney disease. N Engl J Med 2013;369:2492-2503.

7 Chin MP, Reisman SA, Bakris GL, O'Grady M, Linde PG, McCullough PA, Packham D, Vaziri ND, Ward KW, Warnock DG, Meyer CJ: Mechanisms contributing to adverse cardiovascular events in patients with type 2 diabetes mellitus and stage 4 chronic kidney disease treated with bardoxolone methyl. Am J Nephrol 2014;39:499-508.
8 Kohan DE: The renal medullary endothelin system in control of sodium and water excretion and systemic blood pressure. Curr Opin Nephrol Hypertens 2006;15:34-40.

-9 Nasser SA, El-Mas MM: Endothelin ETA receptor antagonism in cardiovascular disease. Eur J Pharmacol 2014;737:210-213. 